\title{
Enhancing Students Motivation in Japanese Conversation (Online Course): through CM
}

\author{
Pika Yestia Ginanjar \\ Universitas Padjajaran, Jatinangor, Indonesia \\ Email: pika.yestia@unpad.ac.id
}

\begin{abstract}
This paper focuses on the study and teaching strategy of Japanese conversation. The objective of the paper is to analyze the motivation of studentson learning through CM as theprimary media of the study, which can help students to improve their level of proficiency. The study used a qualitative method; a case study ona Japanese conversation lecture. Memorizing text or role-playing from existing dialogues is one of many activities used in conversation lectures. The idea of this study is similar to a role-play activity, butby using CM students can also learn pronunciation, articulation, and intonation from the native (actor) directly. This study represents the initial stage of a research project aimed in building students' confidence and improving Japanese fluency. The major finding was that a clear majority of students reported to have a considerably high motivation according to the use of terms 'tanoshikatta' and 'omoshiroi' on their feedback. It says that students were interested to do the assessment.
\end{abstract}

Keywords: second language acquisition; learning strategies; onlinecourse; learning motivation; Japanese study.

\section{Introduction}

Covid-19 pandemic in Indonesia wasspreadingrapidly with unexpectedly severe effects on people's routines. Furthermore, education sector was also affected. All campus activities, both academic and non-academic, were stopped to reduce the risk of this particular virus transmission.

Nevertheless, the education sector must certainly continue to run in line with the obligations of educators, as well as to fulfill the students'rights, that students are entitled to education according to their level.

In connection with the appeal of the Ministry of Education and Culture on this matter, in the field of education, it is proposed that the KBM (Kegiatan Belajar Mengajar/teachng activity) is still conducted online. Started from the middle of March 2020, our university was also one of the universities that transfer face-to-face lecture activities in class into long-distance learning lectures or online course using various platforms.
However, it is undeniable that these changes occurred so suddenly that some academics were not ready to face these changes. It applied for both parties,lecturers as material providers and students as recipients andthe one who is active in learning activities.

Specifically at the beginning of the change period, it can be said that these parties experienced some technical difficulties for example; teaching materials lefton campus, poor internet connection in certain regions, insufficient internet quota,yet could not afford to go to the internet cafe, etc.Hence, it takes time to adapt and find solutions to minimize these constraints, considering the end of this COVID-19 outbreak is not yet visible.

During such condition, as humans we should remain productive, despite all the limitations that exist. In respond to this needour university, faculties, study programs, and even individuals had proposed solution to maintain the longdistance learning system.

Even though this research was carried out in limited conditions, the authors felt 
the need for this research to be presented given the importance of teaching and learning activities, and the authors hope that it can fill a little gap for fellow instructors to utilize the mediaand its effectiveness according to their needs.

The method used was a case study of students who took the 中級会話 chukyuukaiwa 'intermediate level conversation' course. This course is one of the Japanese language proficiency courses.In normal conditions, this lecture requires students to play an active role in speaking, listening, and conducting other conversation activities, as well as making presentations in Japanese on a topic related to Japan.

One of the challenges that existedamong Indonesians Japanese language learners was the lack of confidence onhaving a conversation in Japanese. In fact,when the students take writing test, they can achieve high enough points or scores. This seems to be one of the problems that occur in many universities that have Japanese study programs.

Problems related to self-confidence can be solved by adding more experience to learners in speaking and producing sounds in Japanese. This can be trained both in and outside the classroom. Instructors are required to motivate learners so that they can actively carry out independent learning outside the classroom since class meetings are very limited.

"Helping students to enhance articulateness and forthcomingness - by focusing on known vocabulary employment, sentence construction and clear output - is not only the single most important Oral Communication activity in its own right (one that should be prioritized over grammar and beyond a certain point pronunciation in most instances but helps students become more confident which, in turn, there after helps them -by way of virtuous reinforcement cycle - to become yet more articulate and forthcoming." (William, 2018)

However, with the change in teaching method from face-to-face to online lectures, there are several new obstacles that writer faced as a lecturer in the conversation 会話 kaiwa course, namely a lack of time to interact with students, so there were difficulties in providing teaching material.

As one of the alternatives, we can take references from other research. Research on second language acquisition (SLA) has been widely carried out for English language learning (English as a second language studies); (Huckin, 1999); (William, 2018); (Housen, 2009); (Kukimoto, 2019); (Nagakura, 2019); (Egawa, Yoshiyuki, \& Murai, 2020), and also study on the topic of English teaching materials or teaching methods; (Levy, 2009); (Fukuda, 2019); (Oumi, Fukuda, \& Karasawa, 2020).

However, there is only a limited number of research that addresses Japanese language acquisition, especially those in Indonesia.

There isa discussion of language acquisition strategies that are associated with Japanese language teaching strategies. It was a research conducted by Ibnatul, Krimah, Fahriany, \& Habibi (2018) which focuses on the case study of a Japanese language learner. Therefore, this study intends to focus on teaching Japanese conversation strategies to improve student motivation, so it can lead students to improve their level of proficiency.

A discussion of developing teaching materials in the Japanese Language was conducted by Miyako (2018). Miyako (2018) explores the usage of newspaper articles as teaching material to improve the reading and writing skills of Japanese language foreigner students. However, it did not address the materials for speaking 
either oral conversation.Therefore, this study intends to address this issue.

According to Stephen Krashen's, most widely known in acquisition-learning study, there are five hypotheses (1) The acquisition-learning hypothesis;(2)The monitor hypothesis; (3) The natural order hypothesis (4) The input hypothesis (5) The affective filter hypothesis (Hong, 2008; Schütz, 2019).

On this occasion, this conducted study suggests one of the learning methods that has been applied and receiving a very good response from students. It is hoped that this can become one of the reference materials for fellow lecturers; both working in the same or different fields.

\section{Methods}

The method on this research was a case study with a descriptive qualitative method to describe the results obtained in the form of feedback from students. "Qualitative methods are used to answer questions about experience, meaning and perspective, most often from the standpoint of the participant. These data are usually not amenable to counting or measuring." (Hammarberg, Kirkman, \& de Lacey, 2016).

This case study was conducted on the chukyuukaiwa course, $4^{\text {th }}$ semester.Fourthsemester students can be said to be equivalent to learners who have abilities more or less equivalent to N3. The object of research was the results of feedback from the questionnaire given to students after attending lectures. "This type of research is based on data expressed mostly in the form of words - descriptions, accounts, opinions, feelings, etc. - rather than on numbers. This type of data is common whenever people are the focus of the study, particularly in social groups or as individuals." (Willam, 2011:130)

Assessment was given on April 6, 2020. Students were asked to demonstrate on April 16, 2020, as a midterm exam.

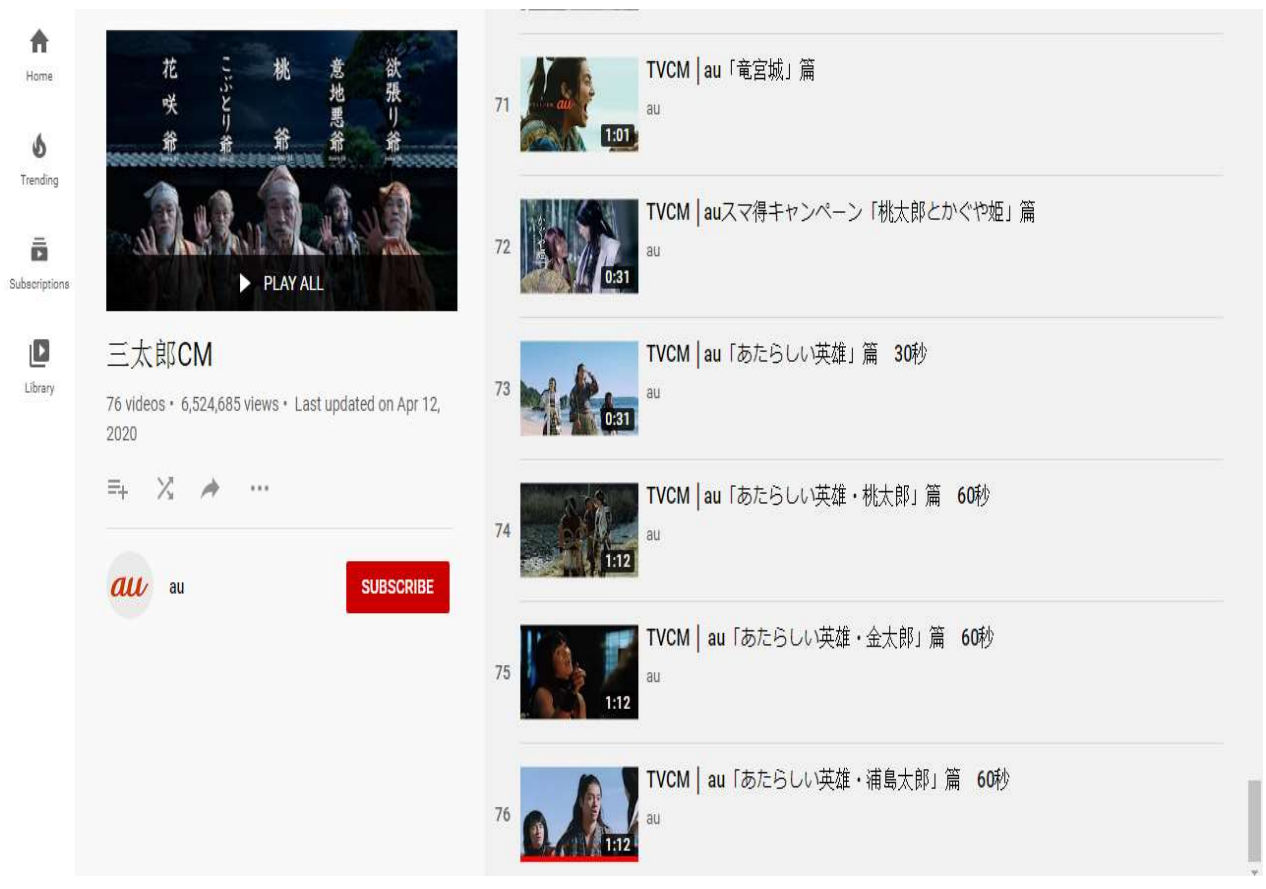

Figure 1 Santarou preference on Youtube (source: au youtubeofficial account) 


\section{Results and Discussion}

This lecture utilized YouTube as teaching material. CM Santarou『三太郎 』 was chosen because the video consists of 76 episodes of whichone video is only 30-60 seconds long, so it does not burden students on internet quota. YouTube as a source of a teaching media helps students who have difficulty with signals or poor internet connection becausenowadays YouTube can be accessed easily from various providers, and is free to access, so students can access it anytime, adjusting to the time when the network is good. While CM Santarou's content is adapted from Japanese folklore which is very well known in Japan, some folklore were adapted and combined into a series of stories.

The video use characters names based on their original story but with a touch of a comedy so that it is easily accepted by the audience. Three main stories namely 『桃 太郎』、『浦太郎』、『金太郎』as well as additional characters such as Kaguyahimealso play an active role in this video. The learning achievement target is the improvement in the ability to express the Japanese language and provide a stimulus to students to be motivated and encouraged to learn Japanese actively.
Following is the flow of learning by utilizing CM Santarou;

(1) CM Santarou'syoutube link was shared to students. (April 6, 2020)

(2) Students wereallowed to freely choose the video of CM Santarou, then instructed to learn the conversations that exist in the CM.

(3) Students then demonstrated it at a specified time. (April 16, 2020)

It was suggested to the students that the conversations in the video or script were not to be recorded because the original Japanese subtitles along with its translation have already been provided, so students can focus more on learning the hatsuon (pronunciation) of native (the characters) that appear on CM Santarou.

(4) The additional task was to write the storyline (arasuji) of the selected video. The goalis to assess students' understanding of the storyline and conversations in the video they have chosen.

(5) Students then wrote feedback about this learning activity.

As a result, students could smoothly demonstrate selected conversations; almost all could memorize the script with good pronunciation. Furthermore, some of them changed their voices when showing different characters to imitate the characters.

Table 1 Feedback From Students

\begin{tabular}{|c|c|}
\hline Initial & Feedback \\
\hline $\mathrm{NZ}$ & $\begin{array}{l}\text { 今回の課題はとても楽しかったと思います。次の課題ではもつと頑張ります。 } \\
\text { Konkai no kadai wa totemo tanoshikatta to omoimasu. tsugi no kadaiwa motto ganbarimasu. } \\
\text { (I think this assessment was a lot of fun. I will do my best in the next task.) }\end{array}$ \\
\hline VR & $\begin{array}{l}\text { 複数の人の会話が独り言になるのはやはり難しいと思いますが、個人的にとても面白 } \\
\text { かったです。表情があつという間を変わらなければならないのが一番面白かった。 } \\
\text { Fukusuu no hito no kaiwa ga hitorigoto ni naru nowa yahari muzukashii to omoimasuga, } \\
\text { kojinteki ni totemo omoshirokatta desu. Hyoujou ga atto iu ma o kawaranakerebanaranai noga } \\
\text { ichiban omoshirokatta. } \\
\text { (It was difficult to have several dialogues alone, but I found it very interesting. The most } \\
\text { interesting thing was when I have to quickly shift my facial expression.) }\end{array}$ \\
\hline
\end{tabular}


IZUMI, Volume 9 No 1, 2020, [Page | 35]

e-ISSN: 2502-3535, p-ISSN: 2338-249X

Available online at: http://ejournal.undip.ac.id/index.php/izumi

Table 1 ...(Continued)

\begin{tabular}{ll}
\hline Initial & Feedback \\
\hline PA & ドキドキしてしまいましたが楽しかったです。 \\
& $\begin{array}{l}\text { Dokidoki shite shimaimashitaga, tanoshikattadesu. } \\
\text { (I was thrilled, yet it was fun.) }\end{array}$
\end{tabular}

BN とても面白くて課題が終わったとしてもその三太郎 CM を何度も見ています。

Totemo omoshirokute kadai ga owatta toshitemo sono Santarou CM o nandomo mite imasu. (It was super fun even after I finished the assessment; I keep on watching the SantarouCM.)

今日は面白いだと思います。そして CM のことは色々なビデオが日本語の発音を勉強 しやすいでした。ありがとうございます。

Kyou wa omoshiroi da to omoimasu. Soshite CM no koto wa iroirona bideo ga nihongo no hatsuon o benkyoushiyasui deshita. Arigatou gozaimasu.

(Today was interesting. furthermore with regard to commercials, various videos made it was easy to learn Japanese pronunciation. Thank you very much.)

FI

私（に）とって、今回の課題は面白いと思いました。声優みたいでした。最初は男性 俳優の声を調整するのは難しかったのですが、準備時間は長かったですから、十分な 練習ができると思いました。その上、先生のおかげで、三太郎についての面白い広告 を知りました。楽しかったです。ありがとうございました。

Watashi (ni) totte, konkai no kadai wa omoshiroi to omoimashita. Seiyuu mitai deshita. Saisho wa dansei haiyuu no koe o chousei suru nowa muzukashikatta no desuga, junbi jikan ga nagakatta desukara, juubun na renshuu ga dekiru to omoimashita. Sono ue, sensei no okagede, Santarou ni tsuite no omoshiroi koukoku o shirimashita. Tanoshikatta desu. Arigatou gozaimashita.

(For me, this assessment was interesting. It was like a voice actor. At first, it was rather difficult to produce the voice of a male actor, but since I had a long time to prepare, I thought that I could practice. Besides, thanks to the teacher for introducing me to CM Santarou. It was fun. Thank you very much.)

LP 声優になったような課題だと思います。CM には 3 人の男優がいるから、一人でどん な声のイントネーションがいいの練習が結構難しいですが、楽しかったです。オンラ インで話した時に少し緊張で恥ずかしい気がするのに、今回の課題は面白かったで す。ありがとうございます。

Seiyuu ni natta youna kadai da to omoimasu. CM ni wa sannin no danyuu ga irukara, hitori de donna koe no intooneeshion ga ii no renshuu ga kekkou muzukashii desuga, tanoshikatta desu. Onrain de hanashita toki ni sukoshi kinchou de hazukashii ki ga suru noni, konkai no kadai wa omoshirokatta desu. Arigatou gozaimasu.

(I think it's a challenge to become a voice actor. There are 3 actors in the CM, so it's quite difficult to contrast voice and intonation alone. Regardless it was fun. Though I felt a little nervous and embarrassed when I spoke online, but this assessment was interesting. Thank you very much.)

LA 実は CM は面白いです。それから最初中間テストはためらったですが大丈夫です。今 日はありがとうございます。

Jitsuwa CM wa omoshiroi desu. Sorekara saisho chunkan tesuto wa tameratta desuga daijoubu desu. Kyou wa arigatou gozaimasu.

(Actually, the CM is interesting. At first, I was hesitant during the test, but it was okay. Thank you for today.)

よろしいだと思います。あの $\mathrm{CM}$ のことを伝えてくれて、ありがとうございます。あ の色々なビデオから日本語の表現を学ばれますのですごく有用です。

Yoroshii da to omimasu. Ano CM no koto o tsutaete kurete, arigatou gozaimasu. Ano iro-irona bideo kara nihongo no hyougen o manabaremasu node sugoku yuuyou desu.

(I think it was fine. Thank you for telling me about that CM. It was very useful because I can learn Japanese expressions from those various videos). 
IZUMI, Volume 9 No 1, 2020, [Page | 36]

e-ISSN: 2502-3535, p-ISSN: 2338-249X

Available online at: http://ejournal.undip.ac.id/index.php/izumi

Table 1 ...(Continued)

\begin{tabular}{|c|c|}
\hline Initial & Feedback \\
\hline MR & $\begin{array}{l}\text { 私にとって、今回の中間試験は面白いと思いました。あの CM のことはいろいろなビ } \\
\text { デオが日本語の発音を勉強しやすいでした。 } \\
\text { Watashinitotte, konkai no chuukan shiken wa omoshiroi to omoimashita. Ano CM no kotowa iro- } \\
\text { irona bideo ga nihon no hatsuon o benkyoushiyasui deshita. } \\
\text { (I think, I found this midterm exam interesting. From that CM, various videos help us to study } \\
\text { Japanese pronunciation.) }\end{array}$ \\
\hline TS & $\begin{array}{l}\text { この課題は面白いだと思います。今回の課題は声優になって難しくて面白かったです。 } \\
\text { そして CMのビデオはよろしくて面白いだと思います。 } \\
\text { Kono kadai wa omoshiroi da to omoimasu. konkai no kadai wa seiyuu ni natte muzukashikute } \\
\text { omoshirokatta desu. Soshite CM no bideo wa yorosikute omoshiroi da to omoimasu. } \\
\text { (I think this task is interesting. This time it was difficult and interesting to become a voice actor. I } \\
\text { also think the CM is nice and interesting.) }\end{array}$ \\
\hline NS & $\begin{array}{l}\text { 私にとって, 今回の課題は面白いと思いました。CMには } 5 \text { 人俳優がいるから, 俳優の声 } \\
\text { をまねることはとても難しかった。でも,楽しかった。あの CM 伝えて, ありがとうご } \\
\text { ざいました。わたしはあの CM が好きです。そして, 全部のあの三太郎の CM を見まし } \\
\text { た。本当に面白いと思いました。 } \\
\text { Watashi ni totte, konkai no kadai wa omoshiroi to omoimashita. CM wa 5nin haiyuu ga irukara, } \\
\text { haiyuu o koe o maneru koto wa totemo muzukashikatta. Demo, tanoshikatta. Ano CM o tsutaete, } \\
\text { arigatou gozaimashita. Watashi wa ano CM ga suki desu.Soshite, zenbu no ano Santarou no CM } \\
\text { o mimashita. Hontou ni omoshiroi to omoimashita. } \\
\text { (For me, this assessment was interesting. Since there are } 5 \text { actors in the CM, it was very difficult } \\
\text { to imitate the actor's voice. But I had a good time. Thank you for telling me that CM. I like that } \\
\text { CM and I watched all the CM of Santarou. I thought it was really interesting.) }\end{array}$ \\
\hline
\end{tabular}

FN

この問題は面白いだと思います。ビデオの中でキャラクターはとても早く話します。こ の問題では、声優になることはとても難しいです。しかし、CM ビデオはとても面白い と思います。ありがとうございます。

Kono mondai wa omoshiroi da to omoimasu. Bideo no naka de kyarakutaa wa totemo hayaku hanashimasu. Kono mondai dewa, seiyuu ni naru koto wa totemo muzukashii desu. Shikashi, CM bideo wa totemo omoshiroi to omoimasu. Arigatou gozaimasu.

(I think this assessment is interesting. The characters speak rather fast in the video. In this task, being a voice actor is very difficult. However, I think the CM video is very interesting. Thank you very much.)

MA

一人で会話をするのはシュールだったんですが、個人的にはとても斬新で楽しかったで す。

Hitori de kaiwa o suru no wa shuuru dattan desuga, kojinteki ni wa totemo zanshin de tanoshikatta desu.

(It was odd to have a conversation alone, but personally it was a brand new experience for me and I enjoyed it.)

SL 最初は、一人で会話するのが変だと思いました。試験のとき、私はとても緊張しまし た。でも、私にとって、このアイディアがとても面白かったです。

Saishowa, hitori de kaiwa suru no ga hen da to omoimashita. Shiken no toki, watashi wa totemo kinchou shimashita. Demo watashi ni totte, kono aidea ga totemo omoshirokatta desu.

(At first, I thought it was weird to talk alone. At the time of the exam, I was very nervous. But for me, this idea is interesting.)

MF とても微妙な感じです。独り言みたいで、面白いです。でもストーリーが短すぎて、な んの物語かちょっと分かりません。これは最初から見るべきかもしれませんね。

Totemo bimyou na kanji desu. Hitori goto mitai de, omoshiroidesu. Demo sutoorii ga mijika sugite, nan no monogatari ga chotto wakarimasen. Kore wa saisho kara miru beki kamoshiremasenne.

(It feels a little bit strange. It's like a soliloquy and it's interesting. But the story is too short and I don't know what the story is about. This may be something that you should watch from the beginning to the end.)

(Data are partially taken, without edits)

Copyright@2020, IZUMI, e-ISSN: 2502-3535, p-ISSN: 2338-249x 
From table 1 above, it can be seen how students was interested attending the lecture. Most stated that they felt attracted to the topic or idea presented, namely the use of CM as content or teaching material. This can be seen from the expression 面白 い/面白かった omoshiroi / omoshirokatta expressed by students. Besides, it can also be seen that the students feel happy, or it can be said that the assessment given feels pleasant. This wasshown by the expression 楽しかった tanoshikatta.

From the use of these two verbs, it can also be concluded that these learning methods can increase students' motivation to learn more. This is in line with the presentation of the motivational subtype by Vallerand in Bukledee (2008) which identified three sub-types of intrinsic motivation; motivation to learn (engaging in an activity for the pleasure and satisfaction of understanding something new); motivation towards achievement (engaging in an activity for the satisfaction of surpassing oneself, coping with challenges and accomplishing or creating something);motivation to experience stimulation (engaging in an activity to experience pleasant sensations). There would appear to be enough in those three categories to keep an individual focused on the learning task (Bukledee, 2008).

Moreover, there are also definitely some uses of verbal expressions that can be explicitly understood as students learning motivation has increased.Here is an example of a declarative sentence expressed by NZ:「次の課題ではもと頑 張ります」Tsugi no kadaidewa motto ganbarimasu. She stated that she would try harder to carry out the next assessment. There seems to be a declaration on this expression.

BN：「課題が終わったとしてもそ の三太郎 $\mathrm{CM}$ を何度も見ています」 kadai ga owatta toshitemo sono Santarou CM o nandomo mite imasu. (It was super fun even after I finished the assessment; I keep on watching the Santarou CM.). This statement can be interpreted that there is a motivation to watch $\mathrm{CM}$ videos, which arises from a sense of interest as a result of the experience during takingthe assessment.

NS：「全部のあの三太郎の CM を 見ました」zenbu no ano Santorou no CM $o$ mimashita (And I watched all the commercials of Santarou). The assessment or assignment on this lecture is for students to simply choose one $\mathrm{CM}$ video, so there is no obligation or demand for them to watch videos other than those they have chosen. However, with the stimulus of one video, there is an interest in watching other videos. This can also be concluded as a result of increased motivation due to a sense of interest in the selected CM video.

As mentioned before about Stephen Krashen's Hypotheses, one of them says that motivation is one of the factors that can affect language acquisition. The affective filter hypothesisassimilates StephenKrashen's view that a number of affective variables play as facilitative, but non-casual role in second language acquisition. These variables include: motivation, self-confidence, anxiety, and personality traits.

Krashen claims that learners with high motivation, self-confidence, a good self-image, a low level of anxiety, and extraversion are better equipped for success in second acquisition (Schütz, 2019).

\section{Conclusions}

The students were very enthusiastic in carrying out the activity as can be seen from the comments given after completing the lecture.It was mentioned that this kind of activity is not only fun but also a stimulus for them to see other videos. Furthermore students gained new knowledge about the figures that emerge in Japanese folklore. Additionally students can learn from native conversations or 
IZUMI, Volume 9 No 1, 2020, [Page | 38]

e-ISSN: 2502-3535, p-ISSN: 2338-249X

Available online at: http://ejournal.undip.ac.id/index.php/izumi

their dialogues when conducting conversations, even though trough a video.

This can be obtained because all this time lectures have been done mostly by memorizing conversational texts without any direction or guidance from native. Meanwhile in this new learning method, students can listen to the audio directly from the characters, so they have a reference on how to say the words, how the intonation, and how to express it.

In this study, some deficiencies are expected to be fulfilled in subsequent studies. This research can be said to be preliminary research. Hencefor future research, various approaches are expected to be added in the research.

\section{References}

Buckledee, Steve. (2008). Motivation and Second Language Acquisition. ELOPE: English Language Overseas Perspectives and Enquiries, 5(1-2), 159-170.Doi: 10.4312/elope.5.1-2.159-170

Egawa Jun, YoshiyukiIchinose, MuraiJinji. (2020). Study on effect of the Adventure Communication Program in the second language learner. The Journal of Kanda University of International Studies(32), 437485.http://id.nii.ac.jp/1092/000016 $57 /$

Fukada, Masaki. (2019). The implementation of multiple learning media in university English courses. Bulletin of Kio University, 16(1), 23-39.Doi: 10.24482/00000036

Hammarberg, K, Kirkman, M, de Lacey S. (2016). Qualitative research methods: when to use them and how to judge them. Human Reproduction, 31(3), 498501.Doi:10.1093/humrep/dev334

Hong, Yang. (2008). On teaching strategies in second language acquisition.US-
China Education Review 5(1), 6167.

Housen, Alex, Kuiken Folkert. (2009). Complexity, accuracy, and fluency in second language acquisition. Applied Linguistics, 30(4), 461473.Doi: 10.1093/applin/amp048

Huckin, Thomas and Coady, James. (1999). Incidental vocabulary acquisition in a second language. Studies in Second Language Acquisition, 21(2), 181-193.

Doi: $10.1017 / \mathrm{s} 0272263199002028$

Ibnatul, Karimah, Virgi Marlany, Fahriany Fahriany, Habibi Firdaus. (2019). Japanese Vocabulary Acquisition Through Anime: A Case Study On Dwimeilinda. IZUMI, 8(2), 65. Doi: 10.14710/izumi.8.2.65-74

Kukimoto, Hirofumi. (2019). Significance of Extensive Reading in Second Language Acquisition and a Classroom Practice Report on It, including the Analysis of Its Effectiveness. Journal of inquiry and research (110) 213-231.

Doi: 10.18956/00007885

Levy, Lawrence Simon. (2009). A Preliminary Assessment of Learner Opinions of Board Games Used for TBL SLA. Department Bulletin Paper: Reports from the Faculty of Clinical Psychology Kyoto Bunkyo University(12), 35-61.

$<$ http://id.nii.ac.jp/1431/00003008>

Miyako, Shoutarou. (2018). Development of Newspaper-based Japanese Teaching Materials for Foreign Students. Bulletin of Shiseikan University, 5, 123133.<https://ci.nii.ac.jp/naid/12000 6464436/en/>

Nagakura, Yuri. (2019). The Outline of Strategy Training for Developing Skills to Teach English to Elementary School Students. Tokoha University Faculty of Education research review(39), 371-390. 
Doi: $10.18894 / 00001735$

Oumi, Akihisa, FukudaKazutaka, KarasawaKazutomo. (2020). On the Utility of Signs and Notices as English Teaching Materials. Komazawa University Bulletin Paper(77), 11-42.

$<$ https://ci.nii.ac.jp/naid/120006816 753/en/>

Schütz, Ricardo E. (2019). Stephen Krashen's Theory of Second Language Acquisition.

$<$ https://www.sk.com.br/sk-krashenglish.html $>$. Online.

Willman, Nicholas. (2011). Qualitative Data Analysis. In Research Methods: the basic. Routledge London. 128-145.

William, Warner Ian. (2018). University Level English Language Oral Communication: Building Confidence and Enhancing Articulateness. Journal of KIBI International University Humanities and Social Sciences(28),99-

114. $<$ https://ci.nii.ac.jp/naid/12000 6413576/en/> 